\title{
Penerapan Data Mining Untuk Memprediksi Penggunaan Daya Listrik Pada PT.PLN (Persero) Rayon Medan Selatan Dengan Menggunakan Metode Regresi Linier Berganda
}

\author{
Novrizal Nazeriandy Siregar *, Yohanni Syahra **, Muhammad Syaifudin ** \\ *Sistem Informasi, STMIK Triguna Dharma \\ **Sistem Informasi, STMIK Triguna Dharma
}

\begin{tabular}{l}
\hline \hline Article Info \\
\hline Article history: \\
Received Jun $12^{\text {th }}, 2020$ \\
Revised Aug $20^{\text {th }}, 2020$ \\
Accepted Oct $26^{\text {th }}, 2020$ \\
\\
\hline Keyword: \\
Daya Listrik, Prediksi, \\
Data Mining, Regresi Linier \\
berganda
\end{tabular}
\begin{abstract}
PT. PLN (Persero) merupakan salah satu badan usaha milik negara (BUMN) yang bergerak dalam bidang penyediaan tenaga listrik yang keberadaan nya sangat di butuhkan masyarakat.makin banyak nya industri yang berskala menengah maupun besar serta pertumbuhan pelanggan yang meningkat setiap tahun nya akan membutuhkan pelayanan dan penyaluran energi listrik secara kontinyu dengan kualitas layanan yang lebih baik. Kegiatan perdagangan, perekonomian dan indutri tumbuh pesat akhir-akhir ini.oleh karena itu permintaan akan tenaga listrik melonjak saat ini dan pertumbuhan nya yang cepat ini di perkirakan akan berlangsung terus untuk tahun-tahun yang datang.

Beberapa solusi yang dapat di gunakan untuk dapat mengatasi masalah tersebut adalah salah satu nya menerapkan aplikasi data mining.Data mining adalah teknikbyang merupakan gabungan metode-metode analisi data untuk memproses data berukuran besar dan merupakan proses menemukan informasi atau pola yang penting dalam basis data berukuran besar.salah satu proses data mining yang akan di gunakan adalah metode prediksi dengan alogritma regresi linear berganda .

Dengan demikian hasil algoritma regresi linear berganda dapat di mempermudah kan pihak PLN dalam memprediksi kebutuhan daya di masa yang akan datang
\end{abstract}

Copyright (C) 2021 STMIK Triguna Dharma. All rights reserved.

\author{
Corresponding Author: \\ Nama : Novrizal Nazeriandy Siregar \\ Program Studi : Sistem Informasi \\ STMIK Triguna Dharma \\ Email : alaladen29280@gmail.com
}

\section{PENDAHULUAN}

Permasalahan perkembangan perumahan terkait dengan penyediaan tenaga listrik dapat dijelaskan sebagai berikut: Seringnya terjadi pemadaman bergilir yang dilakukan oleh PT. PLN Rayon Medan Selatan sehingga banyak masyarakat dan industri mengeluhkan hal ini, Kenaikan Tarif Listrik tidak dibarengi dengan peningkatan pelayanan terhadap konsumen Listrik, Kegiatan usaha baik dilakukan oleh Rumah Tangga maupun oleh kalangan Industri cenderung mengkonsumsi energi listrik yang relatif tinggi dibandingkan dengan pelanggan rumah tangga, Terjadi Urbanisasi yang mengakibatkan meningkatnya jumlah permintaan rumah kost sehingga cendrung pemilik rumah kost menambah kamar atau rumahnya, bahkan sebagian penduduk tidak memperhatikan Izin Mendirikan Bangunan (IMB) dan Peraturan Umum Instalasi Listrik (PUIL) sehingga dapat membayakan keselamatan rumah mereka, Sebagian besar masyarakat dimana daya yang terpasang di rumah mereka tidak sebanding dengan pemakaian mereka artinya daya yang terpasang jauh lebih dari pada yang terpakai ataupun sebaliknya daya yang terpasang kecil sementara kebutuhan akan daya sangat besar, Masih banyak jalan-jalan umum yang belum terpasang Penerangan Jalan Umum (JPU) meskipun masyarakat sudah dibebani Pajak Penerangan Jalan Umum (PPJU) setiap bulannya, Masih terbatasnya penyediaan fasilitas pendistribusian tenaga listrik untuk penyambungan daya, Semakin meningkatnya kebutuhan akan daya listrik seiring dengan pertumbuhan perumahan [1] 
Dalam Ilmu Komputer atau Ilmu Statistika, dikenal sebuah cara untuk mengetahui prediksi dari kebutuhan daya listrik untuk membantu strategi perencanaan dan peningkatan pelayanan oleh PT.PLN Medan Selatan. Ilmu tersebut adalah Data Mining. Data mining merupakan bidang ilmu yang mengajarkan tentang pengolahan data-data yang besar dengan tujuan untuk mencari informasi yang bermanfaat dari data tersebut sehingga data yang menumpuk itu dapat bermanfaat. Data mining adalah proses mencari pola atau informasi menarik dalam data terpilih dengan menggunakan teknik atau metode tertentu. Teknik-teknik, metode-metode, atau algoritma dalam data mining sangat bervariasi. Pemilihan metode atau algoritma yang tepat sangat bergantung pada tujuan dan proses Knowledge Discovery in Database (KDD) secara keseluruhan" [2].

Pengelompokan teknik Data Mining dibagi menjadi 6 bagian yaitu : (1)Deskripsi, (2)Estimasi, (3)Prediksi, (4)Klasifikasi, (5)Pengklasteran, (6)Asosiasi [3]. Teknik yang dapat digunakan untuk mengetahui prediksi penggunaan daya listrik di PT.PLN Medan Selatan adalah teknik Prediksi dan Estimasi, dimana kedua teknik ini dapat mengolah data untuk mengetahui nilai suatu data kedepannya. Namun teknik yang akan digunakan pada karya ilmiah ini adalah Estimasi dimana algoritma yang dijalankan adalah Regresi Linier Berganda.

Teknik Regresi Linier Berganda adalah suatu cara yang dapat digunakan untuk mengetahui hubungan sebuah variabel tak bebas (regressand) dengan sebuah atau lebih variabel bebas (regressor). Analisis regresi merupakan metode analisis yang dapat digunakan untuk menganalisis data dan mengambil kesimpulan yang bermakna tentang hubungan ketergantungan variabel terhadap variabel lainnya, jadi regresi dapat mengetahui estimasi kedepannya dengan melihat variabel bebas yang ada. Bila dalam analisisnya hanya melibatkan sebuah variabel bebas, maka analisis yang digunakan adalah analisis regresi linier sederhana. Hubungan atau korelasi antara dua variabel melalui persamaan regresi sederhana untuk meramalkan nilai dengan yang sudah diketahui nilainya tidak cukup, sebab selain masih ada variabel lainnya. Apabila dalam persamaan analisis regresi melibatkan dua atau lebih variabel bebas, maka regresi ini disebut analisis regresi linier berganda [4]. Untuk menyelesaikan suatu permasalahan prediksi penggunaan daya listrik di PT.PLN Medan Selatan

\section{KAJIAN PUSTAKA}

\subsection{Data Mining}

Data Mining adalah suatu proses penambangan atau penemuan informasi baru yang dilakukan dengan cara mencari sebuah pola atau aturan tertentu dari sejumlah data yang menumpuk dan dikatakan data besar. Data Mining juga dapat diartukan sebagai serangkaian suatu proses dalam mencari atau menggali nilai tambah suatu data yang berupa pengetahuan yang selama ini tidak diketahui secara manual yang pengetahuannya dapat bermanfaat .

Data Mining bukan merupakan suatu bidang yang dapat dikatakan baru. Data Mining adalah sebuah pengembagan dan pencabangan dari ilmu Statistik. Oleh sebab itu Data Mining dan ilmu statistik sangat memiliki keterkaitan satu sama lain Salah satu hal yang menjadi kesulitan dalam mengartikan Data Mining adalah kenyataan bahwa Data Mining mewarisi sangat banyak bidang, aspek dan teknik dari bidang-bidang ilmu lainnya yang sudah mapan terlebih dahulu.

\subsection{Regresi Linier Berganda}

Metode regresi linier berganda adalah sebuah teknik dalam menganalisis data dengan cara kerja yang mencoba dan mencari hubungan antara dua variabel atau lebih khususnya antara variabel- variabel yang mengandung sebab akibat. [5]

Analisis regresi linear berganda sering sebagai analisis preferensi yang digunakan untuk mengetahui pengaruh dari satu variabel atau peubah dengan variabel lainnya. Rumus umum yang digunakan pada analisis regresi adalah

$\mathrm{Y}=\mathrm{a}+\mathrm{bX}+\mathrm{CZ}$

Model regresi linier berganda (Multi-Linear Regression, MLR) adalah sebuah model yang menggambarkan dan menerangkan hubungan satu variabel tergantung (dependent variable) terhadap dua atau lebih variabel penduga (predictor variables). [6]

Regresi linier berganda merupakan perluasan dari regresi linier sederhana Perluasan terlihat dari banyaknya variabel bebas pada model regresi tersebut. Bentuk rumus umum dalam regresi linier berganda dapat dinyatakan secara statistik sebagai berikut:

Dimana:

$$
\mathrm{Y}=\mathrm{a}+\mathrm{b}_{1} \mathrm{X}_{1}+\mathrm{b}_{2} \mathrm{X}_{2}+\ldots .+\mathrm{b}_{\mathrm{n}} \mathrm{X}_{\mathrm{n}}
$$

$\begin{array}{ll}\mathrm{Y} & =\text { Variabel Terikat } \\ \mathrm{X} & =\text { Variabel Bebas } \\ \mathrm{a}, \mathrm{b}_{1}, \mathrm{~b}_{2}, \mathrm{~b}_{\mathrm{n}} & =\text { Parameter Regresi/ Koefisien Regresi }\end{array}$

Kelebihan metode regresi linier berganda diantaranya adalah dalam melakukan generalisasi dan ekstraksi sebuah data dari pola data tertentu, mampu mengakuisisi sebuah ilmu pengetahuan walaupun tidak 
memiliki sesuatu yang pasti, dan mampu melakukan perhitungan secara parallel atau banyak sehingga proses yang dilakukan tidak memerlukan banyak waktu.

\section{METODE PENELITIAN}

Metode Penelitian merupakan proses atau cara ilmiah untuk mendapatkan data yang akan digunakan untuk menyelesaikan masalah dengan dengan mengadakan studi langsung kelapangan untuk mengumpulkan data.Adapun metode dalam penelitian ini mencakup :

1. Teknik Pengumpulan Data

Teknik pengumpulan data berupa suatu pernyataan tentang sifat, keadaan, kegiatan tertentu dan sejenisnya. Pengumpulan data dalam penelitian di CV 28 Motor menggunakan 2 cara berikut merupakan uraian yang digunakan :

a. Wawancara

mendapatkan alur kerja pada objek yang diteliti yang akan digunakan dalam menentukan fiturfitur yang akan dibangun. Pada tahapan wawancara dilakukan dengan cara mewawancarai pemilik Cv.28 Motor tentang penjualan knalpot racing di tokonya. Berdasarkan hasil wawancara yang dilakukan berikut ini adalah variabel-variabel yang menjadi tolak ukur dalam mengPrediksi penjualan knalpot racing.

b. Observasi

Metode pengumpulan data ini digunakan untuk mendapatkan data yang berkaitan dengan peninjauan langsung ke SMA Shop dan ke customer apakah mereka sering merasa kebingungan dalam memilih smartphone yang akan dibeli.

\subsection{Algoritma Sistem}

Metode Regresi Linier Berganda adalah regresi yang meramalkan hubungan antara satu variabel tidak bebas (dependent variabel) (Y) dengan dua atau lebih variabel bebas (independent variabel) $(\mathrm{X} 1, \mathrm{X} 2, \ldots . \mathrm{Xn})$. Dilakukannya analisis ini guna untuk mengetahui hubungan antara variabel bebas dengan variabel tidak bebas. Untuk meramalkan Y, apabila semua nilai variabel bebas diketahui, maka dipergunakan persamaan regresi linier berganda. Hubungan antara Y dan X1,X2,...Xn, yang sebenarnya adalah sebagai berikut:

$\mathrm{Y}=\mathrm{a}+\mathrm{b} 1 \mathrm{X} 1+\mathrm{b} 2 \mathrm{X} 2+\ldots \ldots+\mathrm{bnXn}$

\subsubsection{Penyelesaian}

\subsubsection{Menyederhanakan Persamaan Regresi Linier}

Dari perhitungan koefisien Regresi Linier Berganda di atas, selanjutnya pembuatan persamaan linier antara lain :

1. Untuk persamaan $\sum Y=n a+\mathrm{b}_{1} \sum X_{1}+\mathrm{b}_{2} \sum X_{2}+\mathrm{b}_{3} \sum X_{3}$ dan koefisien regresi, hasilnya sebagai berikut : $1072.86=48 a+490.61 b_{1}+3484.00 b_{2}+11937.00 b_{3}$

2. Untuk persamaan $\sum X_{1} \mathrm{Y}=a \sum X_{1}+\mathrm{b}_{1} \sum X_{1}^{2}+\mathrm{b}_{2} \sum X_{1} X_{2}+\mathrm{b}_{3} \sum X_{1} X_{3}$ dan koefisien regresi, hasilnya sebagai berikut :

$10963.54=490.61 a+5014.63 b_{1}+35616.87 b_{2}+122013.81 b_{3}$

3. Untuk persamaan $\sum X_{2} \mathrm{Y}=a \sum X_{2}+\mathrm{b}_{1} \sum X_{1} X_{2}+\mathrm{b}_{2} \sum X_{2}^{2}+\mathrm{b}_{3} \sum X_{2} X_{3}$ dan koefisien regresi, hasilnya sebagai berikut :

77870.02 $=3484.00 a+35616.87 b_{1}+321342.00 b_{2}+872269.00 b_{3}$

4. Untuk persamaan $\sum X_{3} \mathrm{Y}=a \sum X_{3}+\mathrm{b}_{1} \sum X_{1} X_{3}+\mathrm{b}_{2} \sum X_{2} X_{3}+\mathrm{b}_{3} \sum X_{3}^{2}$ dan koefisien regresi, hasilnya sebagai berikut : 
266788.80 $=11937.00 a+122013.81 b_{1}+872269.00 b_{2}+2971785 b_{3}$

Selanjutnya melaukan proses eliminasi antara persamaan (1) dengan persamaan (2) adalah sebagai berikut : $1072.86=48 a+490.61 b_{1}+3484.00 b_{2}+11937.00 b_{3} \ldots . .[1] \times 490.61$ $10963.54=490.61 a+5014.63 b_{1}+35616.87 b_{2}+122013.81 b_{3} \ldots[2] \times 48$

$526354.9052=23549.232 a+240697.1909 b_{1}+1709281.756 b_{2}+5856399.633 b_{3}$ $526250.1547=23549.232 a+240702.1527 b_{1}+1709609.568 b_{2}+5856662.88 b_{3}$ 104.7505294=0 - $4.961807 b_{1}-327.812 b_{2}-263.247 b_{3} \ldots \ldots . . .(5)$ berikut :

Selanjutnya melaukan proses eliminasi antara persamaan (1) dengan persamaan (3) adalah sebagai $1072.86=48 a+490.61 b_{1}+3484.00 b_{2}+11937.00 b_{3} \ldots \ldots \ldots[1] \times 3484.00$ $77870.01=3484.00 a+35616.866 b_{1}+321342 b_{2}+872269 b_{3} \ldots \ldots . .[3] \times 48$

$3737845.188=167232 a+1709281.756 b_{1}+12138256 b_{2}+41588508 b_{3}$ $3737760.89=167232 a+1709609.568 b_{1}+15424416 b_{2}+41868912 b_{3}$

$84.297776=0-327.812 b_{1}-3286160 b_{2}-280404 b_{3}$ (6) berikut :

Selanjutnya melakukan proses eliminasi antara persamaan (1) dengan persamaan (4) adalah sebagai

$1072.86=48 a+490.61 b_{1}+3484.00 b_{2}+11937.00 b_{3} \ldots \ldots . .[1] \times 11937.00$

$266788.8016=11937.00 a+122013.81 b_{1}+872269 b_{2}+2971785 b_{3}[4] \times 48$

$12806733.07=572976 a+5856399.633 b_{1}+41588508 b_{2}+142491969 b_{3}$

$12805862.48=572976 a+5856662.88 b_{1}+41868912 b_{2}+142645680 b_{3}$

$870.590208=0-263.247 b_{1}-280404 b_{2}-153711 b_{3} \ldots . .(7)$

Setelah melakukan proses eliminasi antara persamaan (1) hingga persamaan (4), maka diperoleh persamaan baru yaitu sebagai berikut :

$104.7505294=0-4.961807 b_{1}-327.812 b_{2}-263.247 b_{3}$

$84.297776=0-327.812 b_{1}-3286160 b_{2}-280404 b_{3} \ldots \ldots \ldots . . .(6)$

$870.590208=0-263.247 b_{1}-280404 b_{2}-153711 b_{3} \ldots . .(7)$

Selanjutnya melakukan proses eliminasi antara persamaan (5) dengan persamaan (6) adalah sebagai berikut :

104.7505294 $=0$ - 4.961807 $b_{1}-327.812 b_{2}-263.247 b_{3}[5]$

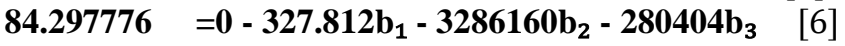

$-3.433848 \mathrm{E}+04=1.626540 \mathrm{E}+03 \mathrm{~b}_{1}+1.074607 \mathrm{E}+05 \mathrm{~b}_{2}+8.935239 \mathrm{E}+12 \mathrm{~b}_{3}$

$-4.182693 \mathrm{E}+02=1.626540 \mathrm{E}+03 \mathrm{~b}_{1}+1.630529 \mathrm{E}+07 \mathrm{~b}_{2}+1.391311 \mathrm{E}+06 \mathrm{~b}_{3}$

$-3.392021 \mathrm{E}+04=0-1.619783 \mathrm{E}+07 \mathrm{~b}_{2} \quad-1.305015 \mathrm{E}+06 \mathrm{~b}_{3} \ldots \ldots \ldots \ldots \ldots \ldots . . . . .(8)$ berikut :

Selanjutnya melakukan proses eliminasi antara persamaan (5) dengan persamaan (7) adalah sebagai

$104.7505294=0-4.961807 b_{1}-327.812 b_{2}-263.247 b_{3}[5]$

$870.590208=0-263.247 b_{1}-280404 b_{2}-153711 b_{3}[7]$

$-27575.26262=1306.180807 b_{1}+86295.52556 b_{2}+69298.98301 b_{3}$

$-4319.700588=1306.180807 b_{1}+1391310.53 b_{2}+762684.3158 b_{3}$

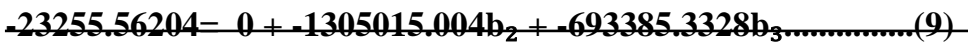

Kemudian setelah melakukan proses eliminasi antara persamaan (5) hingga persamaan (7), maka diperoleh persamaan yaitu sebagai berikut :

$-3.392021 \mathrm{E}+04=0-1.619783 \mathrm{E}+07 \mathrm{~b}_{2}-1.305015 \mathrm{E}+06 \mathrm{~b}_{3}$

$-23255.56204=0+-1305015.004 b_{2}+-693385.3328 b_{3}$ berikut :

Kemudian melakukan proses eliminasi antara persamaan (8) dengan persamaan (9) adalah sebagai 
$\begin{array}{ll}-3.392021 \mathrm{E}+04=0-1.619783 \mathrm{E}+07 \mathrm{~b}_{2}-1.305015 \mathrm{E}+06 \mathrm{~b}_{3} & {[8] \mathrm{x}-1305015.004} \\ -23255.56204=0+-1305015.004 \mathrm{~b}_{2}+-693385.3328 \mathrm{~b}_{3} & {[9] \mathrm{x}-1.619783 \mathrm{E}+07}\end{array}$

$44266384652=2.11384 \mathrm{E}+13 \mathrm{~b}_{2}+1.70306 \mathrm{E}+12 \mathrm{~b}_{3}$

$3.7669 \mathrm{E}+11=2.11384 \mathrm{E}+13 \mathrm{~b}_{2}+1.12313 \mathrm{E}+13 \mathrm{~b}_{3}$

$-3.32423 \mathrm{E}+11=-9.52827 \mathrm{E}+12 \mathrm{~b}_{3}$

$\mathrm{b}_{3}=-3.32423 \mathrm{E}+11 /-9.52827 \mathrm{E}+12$

$b_{3}=0.034888089$

Hasil $b_{3}$ dimasukkan ke antara persamaan (8) atau persamaan (9), dalam hal ini menggunakan persamaan (8) adalah sebagai berikut :

$-3.392021 \mathrm{E}+04=0-1.619783 \mathrm{E}+07 \mathrm{~b}_{2}-1.305015 \mathrm{E}+06 \mathrm{~b}_{3}$

$-3.392021 \mathrm{E}+04=0-1.619783 \mathrm{E}+07 \mathrm{~b}_{2}-1.305015 \mathrm{E}+06(0.034888089)$

$-3.392021 \mathrm{E}+04=0-1.619783 \mathrm{E}+07 \mathrm{~b}_{2}-45529.47936$

$11609.26809=-16197830.98 b_{2}$

$\mathrm{b}_{2}=11609.26809 /-16197830.98$

$b_{2}=\mathbf{- 0 . 0 0 0 7 1 6 7 1 7}$

Hasil $b_{2}$ dan $b_{3}$ dimasukkan antara persamaan (5), (6) atau persamaan (7), dalam hal ini menggunakan persamaan (5) adalah sebagai berikut :

$104.7505294=0-4.961807 b_{1}-327.812 b_{2}-263.247 b_{3}$

$104.7505294=0-4.961807 b_{1}-327.812(-0.000716717)-263.247(0.034888089)$

$104.7505294=0-4.961807 b_{1}+0.23494858-9.184184711$

$113.6997656=-4.961807 b_{1}$

$\mathrm{b}_{1}=113.6997656 /-4.961807$

$b_{1}=\mathbf{- 2 2 . 9 1 4 9 9 1 5 7}$

Selanjutnya hasil $b_{1}, b_{2}, b_{3}$ dimasukkan antara persamaan (1), (2), (3) atau persamaan (4), dalam hal ini menggunakan persamaan (1) adalah sebagai berikut :

$1072.86=48 a+490.61 b_{1}+3484.00 b_{2}+11937.00 b_{3}$

$1072.86=48 a+490.61(-22.91499157)+3484(-0.000716717)+11937(0.034888089)$

$1072.86=48 a-11242.3011-2.497043591+416.459116$

$11901.1993=48 a$

$a=11901.1993 / 48$

$a=247.941652$

Dari hasil perhitungan $a, b_{1}, b_{2}, b_{3}$ di atas jika hasilnya dimasukkan ke dalam persamaan berikut : $\mathrm{Y}=a+\mathrm{b}_{1} \mathrm{X}_{1}+\mathrm{b}_{2} \mathrm{X}_{2}+\mathrm{b}_{3} \mathrm{X}_{3}$

Maka akan menghasilkan persamaan di bawah ini :

$Y=247.941652-22.91499157 X_{1}-0.00071671 X_{2}+0.034888089 X_{3}$

Pengujian kasus berdasarkan persamaan :

Diasumsikan bahwa Jumlah Pemakai $($ User) $=10.000$ user, Jumlah Pemasangan Daya Baru = 43, Jumlah Pemakaian Fasilitas Umum = 500 maka rumusnya adalah sebagai berikut:

$\mathrm{Y}=a+\mathrm{b}_{1} \mathrm{X}_{1}+\mathrm{b}_{2} \mathrm{X}_{2}+\mathrm{b}_{3} \mathrm{X}_{3}$

$Y=247.941652-22.91499157 X_{1}-0.00071671 X_{2}+0.034888089 X_{3}$

$Y=247.941652-22.91499157(10)-0.00071671(43)+\mathbf{0 . 0 3 4 8 8 8 0 8 9}(500)$

$\mathrm{Y}=36.20496191$

$\mathrm{Y}=36.20496191$ dikali 1.000 .000

$Y=36204961.91 \mathrm{Kwh}$

Jurnal SAINTIKOM Vol. 20, No. 1, Februari 2021 : $20-27$ 
Berdasarkan perhitungan di atas dapat diperoleh nilai prediksi penggunaan listrik untuk januari tahun 2020 adalah $\mathbf{3 6 2 0 4 9 6 1 . 9 1 ~} \mathbf{k W H}$.

\section{IMPLEMENTASI DAN PENGUJIAN}

1. Form Login

Form Login digunakan untuk mengamankan sistem dari user-user yang tidak bertanggung jawab sebelum masuk ke Menu Utama. Berikut adalah tampilan Form Login :

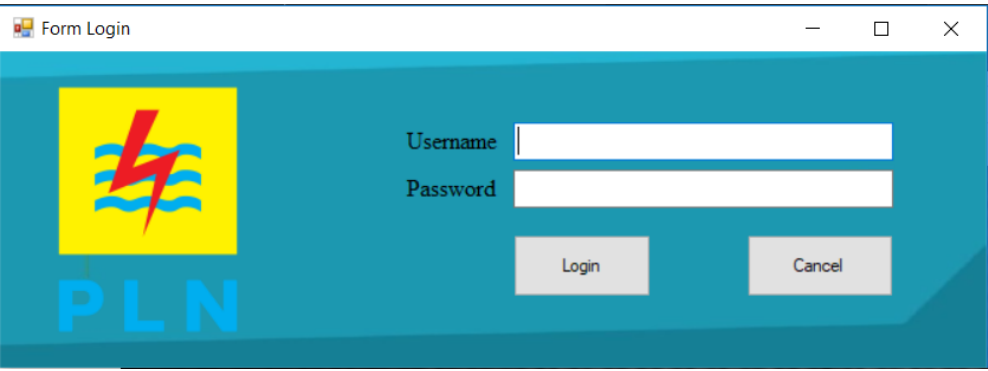

Gambar 5.1 Form Login

Berikut keterangan pada gambar 5.1 Form Login :

a. Tombol Login digunakan untuk mem-validasikan username dan password yang telah kita isi pada kotak teks yang disediakan.

b. Tombol Cancel digunakan untuk menutup form login.

2. Form Menu Utama

Form Menu Utama digunakan sebagai penghubung untuk Form Data Penggunaan Daya Listrik, Form Analisis Estimasi dan Form Laporan. Berikut ini adalah tampilan dari form menu utama.

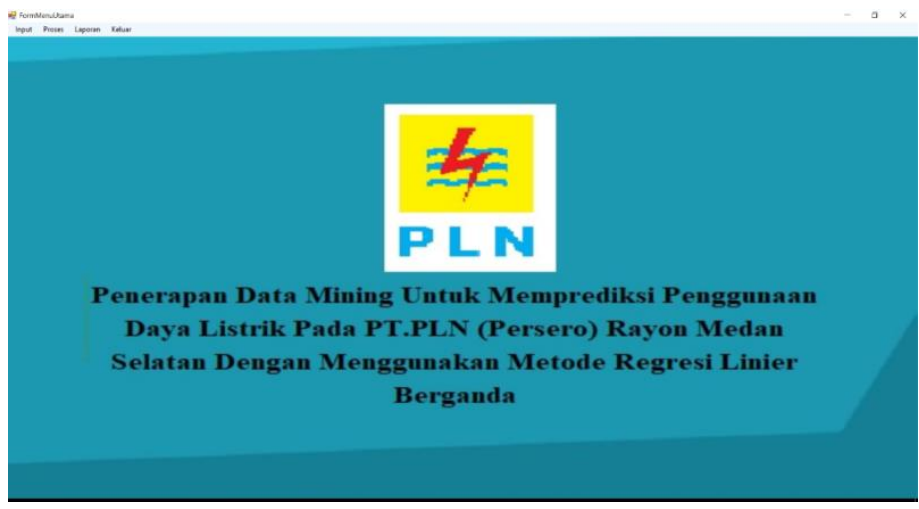

Gambar 5.2 Form Menu Utama

3. Form Data Penggunaan Daya Listrik

Form Data Penggunaan Daya Listrik adalah Form yang digunakan untuk mengelola Data Penggunaan Daya Listrik yang ada pada Sistem. Berikut adalah tampilan form Data Penggunaan Daya Listrik: 


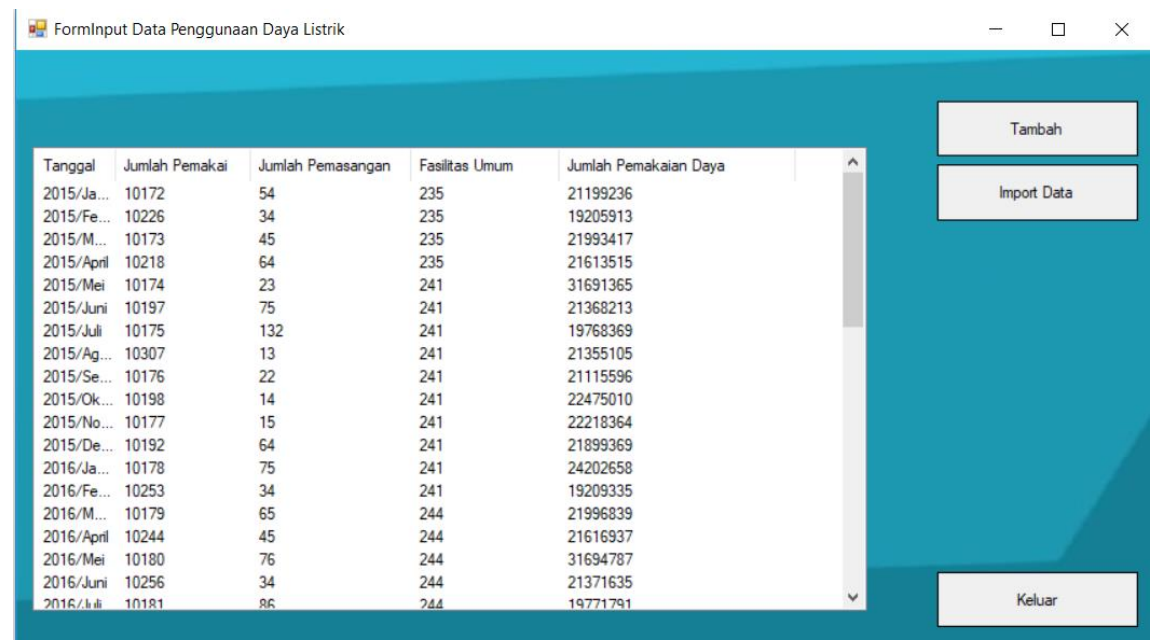

Gambar 5.4 Form Data Penggunaan Daya Listrik

Berikut keterangan pada gambar 5.4 form Data Penggunaan Daya Listrik:

a. Tombol Tambah digunakan untuk menambahkan Data Penggunaan Daya Listrik.

b. Tombol Import digunakan untuk memasukkan Data Penggunaan Daya Listrik secara menyeluruh dari file excel.

c. Tombol Hapus digunakan untuk menghapus Data Penggunaan Daya Listrik yang telah ada sebelumnya

d. Tombol Keluar digunakan untuk menutup form.

4. Form Analisis Prediksi

Form Analisis Prediksi adalah Form yang digunakan untuk mencari Prediksi Pemakaian Daya KWH. Berikut adalah tampilan form Analisis Prediksi:

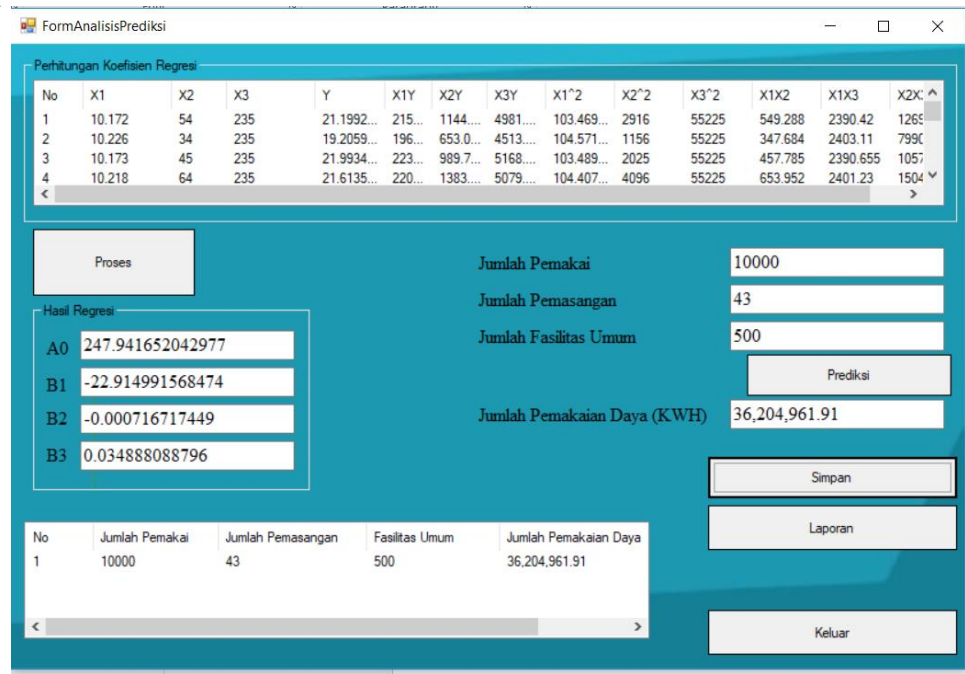

Gambar 5.5 Form Analisis Prediksi

Berikut keterangan pada gambar 5.5 form Analisis Prediksi:

1. Tombol Proses digunakan untuk mencari nilai koefisien linier dan melakukan Prediksi.

2. Tombol Simpan digunakan untuk menyimpan hasil Prediksi.

3. Tombol Laporan digunakan untuk menampilkan hasil laporan Prediksi.

4. Tombol Keluar digunakan untuk menutup form.

\section{Form Laporan}

Form Laporan adalah form yang digunakan untuk menampilkan hasil dari algoritma Regresi Linier tentang memprediksi jumlah penggunaan daya listrik di PLN Rayon Medan Selatan. Berikut ini adalah tampilan dari form Laporan: 


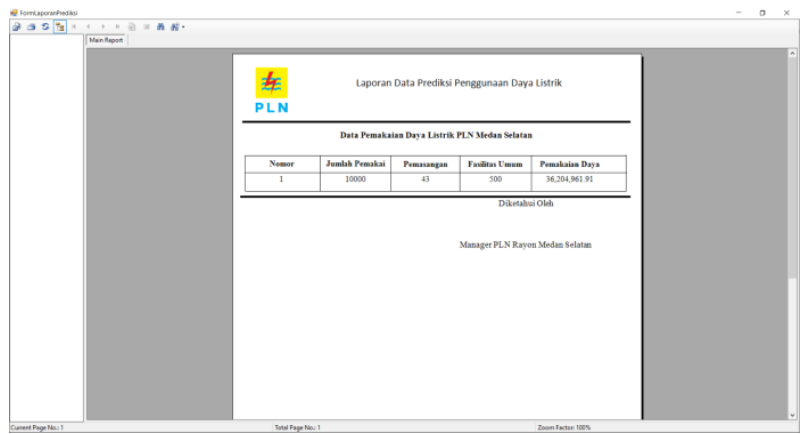

Gambar 5.7 Form Laporan

\section{KESIMPULAN}

Berdasarkan analisa pada permasalahan yang terjadi dalam kasus yang diangkat tentang memprediksi jumlah penggunaan daya listrik dengan Metode Regresi Linier Berganda di PT.PLN Medan Selatan, maka dapat ditarik kesimpulan sebagai berikut :

1. Dalam cara menganalisa penggunaan daya listrik di PT.PLN Medan Selatan menggunakan data mining dengan algoritma Regresi Linier Berganda digunakanlah teknik pengolahan data / penambangan data dari data yang menumpuk dengan cara KDD yaitu dimulai dari pengumpulan data pembersihan data dan sampai ke tahap evaluasi/interpretasu sehingga menjadi informasi yang berguna.

2. Metode Regresi Linear Berganda mampu memprediksi penggunaan daya listrik di PT.PLN Medan Selatan dengan akurat berdasarkan data jumlah pemakai, jumlah pemasangan baru dan jumlah fasilitas umum di Medan Selatan yang menggunakan daya listrik.

3. Dalam merancang program untuk memprediksi penggunaan daya listrik di PT.PLN Medan Selatan dapat menggunakan bantuan pemodelan UML terlebih dahulu, dengan kata lain aplikasi digambarkan pada bentuk Use Case Diagram, Activity Diagram dan Class Diagram. Kemudian dilakukan pengkodean dengan perancangan tersebut

\section{UCAPAN TERIMA KASIH}

Terima kasih kepada dosen pembimbing dan pihak-pihak yang mendukung penyelesaian jurnal penelitian ini.

\section{REFERENSI}

[1] E. J. Mening, "PROBLEMATIK YURIDIS PT. PERUSAHAAN LISTRIK NEGARA (PERSERO) DALAM PELAKSANAAN UNDANG UNDANG REPUBLIK INDONESIA NOMOR 30 TAHUN 2009 TENTANG KETENAGALISTRIKAN," Hukum Ekonomi Bisnis, 2013.

[2] Yuli Mardi, "Data Mining : Klasifikasi Menggunakan Algoritma C4.5 Yuli Mardi," Jurnal Edik Informatika, no. ISSN : 2407-0491

[3] A. M. Alfannisa Annurullah Fajrin1, "PENERAPAN DATA MINING UNTUK ANALISIS POLA PEMBELIAN KONSUMEN DENGAN ALGORITMA FPGROWTH PADA DATA TRANSAKSI PENJUALAN SPARE PART MOTOR," Kumpulan jurnaL Ilmu Komputer (KLIK), vol. 5, no. ISSN: 2406-7857, 2018.

[4] Amrin, "DATA MINING DENGAN REGRESI LINIER BERGANDA UNTUK PERAMALAN TINGKAT INFLASI," Jurnal Techno Nusa Mandiri, vol. XIII, no. 1, 2016.

[5] S. Sulistyono and W. Sulistiyowati, "Peramalan Produksi dengan Metode Regresi Linier Berganda," PROZIMA (Productivity, Optimization and Manufacturing System Engineering), vol. 1, no. 2, p. 82, 532018.

[6] A. Rachman and d. Hadi Al Rasyid, "MODEL PERAMALAN KONSUMSI BAHAN BAKAR JENIS PREMIUM DI INDONESIA DENGAN REGRESI LINIER BERGANDA". 